Review Article

\title{
An integrated approach to sustainable development, National Resilience, and COVID-19 responses: The case of Japan
}

\author{
Andrew DeWit ${ }^{\mathrm{a}}$, Rajib Shaw ${ }^{\mathrm{b}}$, Riyanti Djalante ${ }^{\mathrm{c}, *}$

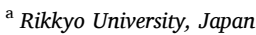 \\ ${ }^{\mathrm{b}}$ Keio University, Japan \\ ${ }^{\mathrm{c}}$ United Nations University - Institute for the Advanced Study of Sustainability (UNU-IAS), Japan
}

\section{A R T I C L E I N F O}

\section{Keywords:}

COVID-19

Japan

Fiscal stimulus

Resilience

Sustainability

Society 5.0

Sustainable development goals (SDGs)

\begin{abstract}
A B S T R A C T
The COVID-19 pandemic has led to historic economic fallout. To protect public health and stabilize incomes, governments have implemented massive fiscal stimulus packages. These fiscal supports are crucial, though there is concern that sustainable and resilient development will be sacrificed in the rush to preserve incomes and industries. The aim of the paper is to review whether the Japanese governments' responses in terms of financial stimulus considers longer term resilience and sustainability. This paper reviews pertinent academic literature and publicly available data from governments and organisations. The research is a rapid analysis of emerging information provided by the government of Japan and other international organisations. Using the case of Japan, this paper suggests that it is possible both to protect public health and essential services, while also promoting resilience and sustainability. Japan's integrated solutions show that pandemic response can include accelerated decarbonization and resilient, sustainable development. The paper also warns also that failure to act on longterm sustainability risks increased inequality, higher opportunity costs, cascading hazards, and further retreat from planetary thinking and globalism.
\end{abstract}

\section{Introduction}

This paper begins by reviewing the global developments, then turns to the specifics of the Japanese case. We conclude with a section on strategies towards further bolstering long-term sustainability and resilience building. As to global developments, the World Health Organization (WHO) officially declared COVID-19 a pandemic on March 11, 2020 [1], and by May 15 was reporting over 3.4 million confirmed cases [2]. It soon became clear that the pandemic's social and economic impacts were accelerating with no modern precedent. Economic impacts that unfolded over a few years during the Great Depression now erupt within a few weeks. By April 18, the International Monetary Fund (IMF) had already projected the pandemic's total 2020-2021 costs to be USD 9 trillion, equivalent to the combined size of the German and Japanese economies [3]. A month later, on June 24, the IMF raised that figure to USD 12 trillion [4]. On April 7, the International Labour Organization (ILO) estimated global job losses in the second quarter (April-June) of 2020 to equate to 195 million full-time positions [5]. By June 30, the ILO had more than doubled that estimate, to 400 million [6]. These new data are almost certain to become under-estimates.
Amidst the chaos, astute global leaders have sought to articulate a collective response. On March 19 UN Secretary General Antonio Guterres warned that "[w]e are facing a global health crisis unlike any in the 75-year history of the United Nations" [7]. Guterres emphasized the imperative of solidarity, hope and a coordinated global response to counter a "human crisis" [8]. The March 26 G20 Leaders' Statement on COVID-19 from their Extraordinary Summit echoed this sentiment, declaring that "[c]ombatting this pandemic calls for a transparent, robust, coordinated, large-scale and science-based global response in the spirit of solidarity [9].

Spending programmes to cope with the pandemic's impacts have increased in scale and frequency, both multilaterally and domestically. As to the former, on March 25 the UN launched a USD 2 billion global humanitarian response plan (GHRP) to fund the fight against COVID-19 in the world's poorest countries [10]. March 26 saw the G20 pledge USD 5 trillion of stimulus (both multilateral and country-level) into the global economy, as part of targeted fiscal policy, economic measures, and guarantee schemes to counteract the pandemic's social, economic and financial impacts. On March 31, the EU Solidarity Fund's scope was broadened to include major public health emergencies. The FY 2020

\footnotetext{
* Corresponding author.

E-mail address: djalante@unu.edu (R. Djalante).
} 
financing of roughly EUR 800 million is aimed at supporting member countries' action to protect their populations and prevent viral spread [11].

Country-level fiscal stimulus packages have been far more numerous and aggressive. Table 1 summarizes the cumulative fiscal stimulus, in currency amounts and share of GDP, for several major countries as of April 20. For example, April 7 saw the Japanese Cabinet approve the country's largest ever stimulus of JPY 108 trillion (approximately USD 1 trillion), subsequently increased to JPY 117.1 trillion on April 20. On May 26, that amount was doubled, with the total reaching JPY 234.2. Most observers expect several more stimulus packages in Japan and elsewhere as the public-health crisis worsens.

Measures to recover from the present crisis are virtually certain to include long-term investments in health, energy, water, transport, and other critical infrastructure [15]. Climate-aware individuals and institutions recognize the present crisis as an opportunity - indeed an imperative - for resilient, decarbonizing and equitable structural change. Certainly COVID-19 has dramatically reshaped the policymaking debate by: 1) bolstering public authority over private agency, 2) elevating collaborative planning over reliance on price signals, 3) expanding the scope of all-hazard resilience to emphasize pandemic risks, and 4) vastly increasing public awareness of the need for holistic resilience. Thus, back on March 31, UN Secretary General Guterres was able to insist that "[t]he recovery from the COVID-19 crisis must lead to a different economy" without attracting a flurry of criticism [16].

Yet many questions whether this ideational change will become institutionalized and lead to inclusive resilience. There is no guarantee that national-level countermeasures will come to embody the 2030 Agenda, let alone serve as a basis for productive global cooperation. There is also no consensus on precisely what constitutes best practice in decarbonizing and disaster-resilient infrastructure, and hence no simple guide for selecting and implementing such urban systems.

Many voices equate sustainability with green energy - notable solar and wind - within a context wherein "green recovery" has become the byword for transcending fossil fuels. But simply investing in more solar and wind does not seem sufficient. Data on global renewable investment between 2010-19 show that China is the leader, followed by the US and Japan [17]. But those prodigious investments alone did not reduce emissions, increase equity, and otherwise achieve the 2030 Agenda goals. Equally, if not more important, is the resource-efficiency of urban and semi-urban communities, the inclusivity of governance, and the myriad other factors that are key to the 2030 Agenda.

The scope of the challenge is underscored by International Energy Agency estimates that the COVID-19 shock - though unprecedented will only lead to an $8 \%$ reduction in $\mathrm{CO} 2$ emissions in 2020 , relative to 2019 [18]. To be sure, that decline in emissions accords with the call for annual $\mathrm{CO} 2$ reductions of $7.6 \%$ to limit warming to $1.5^{\circ}$ [19]. But the IEA warns that 2020's decline in emissions could be followed by a massive increase unless stimulus plans emphasize low-carbon and decarbonizing recovery. Just as unprecedented economic chaos alone does not eliminate emissions, fiscal stimulus does not necessarily lead to "build back better."

Hence the urgency of examining the evidence on what countries are doing. Observers note that some countries - notably China, Germany and South Korea - are thinking of including sustainability goals in upcoming

Table 1

COVID-19 fiscal stimulus, \% GDP (as of July 1, 2020) [12,14].

\begin{tabular}{lll}
\hline Country & Fiscal Stimulus (Amount) & Fiscal Stimulus (\% GDP) \\
\hline Japan & JPY 234.2 trillion (USD 2 trillion) & 42.2 \\
US & USD 2.9 trillion & 14 \\
Germany & EUR 913 billion & 26.9 \\
France & EUR 425 billion & 19 \\
China & RMB 4.2 trillion & 4.1 \\
\hline
\end{tabular}

Source: Japanese Cabinet Secretariat [12,13]; IMF [3,4,14]. fiscal stimulus [20]. But the evidence suggests Japan is already battling COVID-19 and building climate resilience at the same time. This paper shows that Japan embeds holistic resilience and sustainability in its fiscal stimulus packages. Past and present performance indicate Japan's emphasis on integrated solutions can help accelerate decarbonization and foster resilient, sustainable development while countering COVID-19's myriad impacts. Japan is one example of how COVID-19 countermeasures are being used to bridge national and international imperatives.

The next section turns to the fiscal and institutional details of the Japanese case.

\section{Japan's fiscal stimulus in context}

As noted earlier, Japan's COVID-19 fiscal countermeasures total JPY 234.2 trillion as of July 1, 2020. Much expert commentary on Japan's first round of fiscal stimulus pointed to the fact that it was not all new finance, but rather built on Japan's December 2019 fiscal stimulus [21]. In other words, the criticism largely suggested that JPY 108 trillion size of Japan's April 7 fiscal stimulus was exaggerated. But this appraisal of the scale of Japan's April 2020 fiscal stimulus deflected attention from the important resilience-oriented content of the December 2019 stimulus. The December stimulus had nothing to do with COVID, and instead responded to Japan's need to further bolster holistic disaster resilience in the wake of floods, seismic events, power outages, and other shocks during 2018 and 2019. We present the main elements of the December 2019 package in Table 2.

Table 2 shows that there were three key pillars in the December 2019 stimulus: National Resilience Plans (NRP) and disaster reconstruction; economic risk countermeasures; and "Post 2020 Olympic Games" legacy investment in Society 5.0, SDGs-inclusive society. Of course, the 2020 Olympic Games are postponed to 2021, and in the end may not even be held. But that does not mean the investment in critical infrastructures is, ipso facto, wasteful.

The table also separates the JPY 13.2 trillion public spending from the JPY 26 trillion total of public and private spending. The latter figure is achieved via national government support for local government spending (through direct and indirect subsidies), low-interest loans to foster business investment, and similar mechanisms.

In terms of precise content among the three categories, the NRP share is JPY 2.8 trillion, investments in Society 5.0 and SDGs (both investment in infrastructure and training human resources) JPY 781.6 billion. The NRP projects are underpinned by the idea that "coping with climate change is also conducive to disaster prevention," and the Society 5.0/ SDG initiatives explicitly target zero-emissions technology (such as natural refrigerants), energy efficiency, and related decarbonization [22].

The subsequent fiscal stimulus (cumulative to April 20) built on this legacy by doubling down on the NRP, SDGs and Society 5.0 roles. The package also included JPY 15 trillion for restructuring supply chains to re-shore or at least further diversify (eg, among ASEAN countries) the production of critical medical and related materials (pharmaceuticals, masks, ventilators, sanitizers, and other items). Moreover, consistent with the December 2019 approach, the measures undertaken in April ramp up the efforts on Society 5.0, digital transformation, decarbonization, and other measures specifically to reduce the risks of future pandemics. The package also emphasizes SDGs-style multilateral

Table 2

December 2019 Fiscal Stimulus (JPY trillion) (Source [12].

\begin{tabular}{ll}
\hline Measure & Public Spending \\
\hline NRP and Disaster Reconstruction & 5.8 \\
Economic Risk & 3.1 \\
Post 2020 Olympic Games & 4.3 \\
Total & 13.2 \\
\hline
\end{tabular}


engagement on water systems, public health and other critical infrastructure via JETRO, JBIC, JICA and through UNICEF, IMF, WBG, ADB, and other agencies where Japan has a track record of close collaboration.

The above is not to insist that Japan is a leader in fighting COVID-19. In the May 7 Financial Times former UN Executive Secretary of the UN Framework Convention on Climate Change, Christiana Figueres, included Japan among the countries that "acted in line with the risks." But it is also the case that, like almost all other countries, Japan's preCOVID all-hazard disaster resilience grossly under-estimated the risks of a pandemic. And again, like most other countries, Japan's pandemic response was delayed and remains inadequate. Yet it is also true that Japan's 20,261 confirmed cases and 982 fatalities as of July 9, are much lower than most of its peer countries in the G20 and OECD [23]. But in any event, this paper is not the venue to compare the relative merits of differentiated epidemiological responses to COVID-19 per se, particularly because much remains unclear about the pandemic's trajectory and what is effective in the face of it.

\section{Japan's integrated paradigm: society 5.0, SDGs and National Resilience}

\subsection{Society 5.0 and national SDGs initiatives}

Far more important for our purposes here is that Japan's actions are evolving in a holistic paradigm. For one thing, they are part of an in-

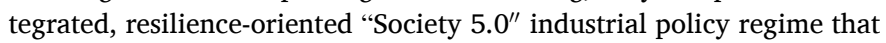
predated COVID-19 [24,25]. We saw earlier that this policy regime was already heavily funded in Japan's pre-COVID, December 2019 stimulus. And that pre-COVID stimulus comprises a core element of the larger April 20 stimulus noted earlier. Society 5.0's policy arms include such critical cyber-physical linkages as "post $5 \mathrm{G}$ " next-generation communications, remote-sensing for disaster risk reduction, digitalization in smart cities, 3-D mapping for compact cities, monitoring and controls for integrating variable renewable energy, and other means to bolster evidence-based collaborative governance [25]. Japan's Society 5.0 is also directly tied to the 2030 Agenda's Sustainable Development Goals (SDGs). Indeed, Japan's SDGs initiative appears to be unique among the developed countries: its multi-level SDGs collaboration deliberately uses the SDGs' 17 goals and 169 targets to focus local government initiatives on myriad domestic challenges in combination with overseas engagement and contributions. In short, Japan does not see SDGs as external aid but rather as a platform for integrating sustainable domestic and overseas development [26].

As is shown in Table 3, Japan has organized a broadly inclusive Local SDGs Public-Private Collaborative Platform. By the end of June, the platform included 631 local governments in addition to most of the national government's central agencies. It also includes 1318 business firms, research institutions, NPOs and other members, bringing the total to 1962 members. Table 4 also shows the ongoing results of the Japanese Cabinet Office's efforts to disseminate best practice. Since 2018, the Cabinet Office has opened a competition for subnational governments to be designated as SDG Future Cities and for particularly well-integrated initiative to be designated as Model Cases. As of April of 2020, there are 60 SDG Future Cities and 20 Model Cases.

A further important platform context for shaping Japanese action is

\section{Table 3}

Japan's local SDGs public-private collaborative platform (as of April 2020), Source: http://future-city.go.jp/platform/.

\begin{tabular}{ll}
\hline Member Class & Number \\
\hline Subnational Governments & 631 \\
Central Agencies & 13 \\
Private Firms and others & 1318 \\
Total Membership as of end June 2020 & 1962 \\
\hline
\end{tabular}

Table 4

Japan's local SDGs communities and model cases (as of April 2020) Source: https://sdgs-support.or.jp/journal/sdgs-future-city/.

\begin{tabular}{ll}
\hline Category and Year & Number \\
\hline 2018 SDG Future Cities & 29 \\
2018 SDG Model Cases & 10 \\
2019 SDG Future Cities & 31 \\
2019 SDG Model Cases & 10 \\
Total Cities and Cases & Cities: 60, Model Cases: 20 \\
\hline
\end{tabular}

its Smart City Public-Private Collaborative Platform, whose membership is itemized in Table 5. Of particular note is the growing number of local governments, at present 115 . The platform also includes 120 observers, and is yet another venue in which decarbonizing and inclusive Society 5.0, SDGs, and DRR best practice are shared among a multiplicity of stakeholders.

A more recent platform is Japan's Green Infrastructure PublicPrivate Collaborative Platform. The local government membership includes Sendai City (the host city for the SFDRR), Tokyo, and other influential cases. Moreover, the important role of central agencies is coupled with the participation of business, academe, NPOs and other stakeholders whose collective expertise encompasses water, energy, construction, and other areas crucial to designing and implementing comprehensive green-infrastructure solutions (Table 6).

\subsection{National Resilience Plans (NRP)}

One of Japan's key governance platforms for designing, implementing and revising integrated policy is National Resilience [27]. National Resilience predates the 2030 Agenda's Sendai Framework on Disaster Risk Reduction (SFDRR), formally adopted in 2015, but closely parallels its content by emphasizing all-hazard disaster preparation in advance, building back better, and "whole of government" inclusive governance. National Resilience also encompasses smart communications, sustainable energy systems, resilient water networks, and the other critical infrastructures that compose holistic resilience.

Japan's national and subnational governments are closely linked in a rapidly expanding portfolio of national and subnational National Resilience Plans (NRPs) that have legal precedence over other plans. NRPs are aimed at bolstering the country's resilience to natural disasters and other hazards, as well as fostering the capacity to recover from such disasters when they occur. Since 2014, there have been 2 iterations $(2014,2018)$ of the NRP Basic Plan as well as 6 annual action plans that decide and then monitor the planning cycle and the achievement of Key Performance Indicators (KPI). These KPIs include hard measures, such as monitoring hazards via smart sensors, strengthening back-up power for hospitals and other facilities, reinforcing flood-control systems, and hardening critical communications infrastructure. The KPIs also include soft measures, such as skill-building, risk communication, and measures to break down governance silos. In the 2019 revision of the original 5year NRP basic plan, the number of KPIs had increased to 179. Moreover, Japanese National Resilience has been funded at roughly JPY 5 trillion per year since FY 2018. The investments finance soft and hard measures in addition to training and international engagement.

Table 5

Japan's smart city public-private collaborative platform (as of June 2020) (Source: https://www.mlit.go.jp/scpf/about/index.html).

\begin{tabular}{ll}
\hline Platform Member Class & Number \\
\hline Subnational Governments & 115 \\
Central Agencies & 11 \\
Businesses, Research Centres, and others & 359 \\
Business Associations & 2 \\
Total Membership & 487 \\
\hline
\end{tabular}


Table 6

Japan's green infrastructure public-private collaborative platform (as of March 19, 2020) (Source: http://www.mlit.go.jp/report/press/sogo10_hh _000216.html).

\begin{tabular}{ll}
\hline Member Class & Number \\
\hline Subnational Governments & 23 \\
Central Agencies & 4 \\
Businesses, Research Centres, and others & 150 \\
Individual Memberships & 232 \\
Total Membership & 409 \\
\hline
\end{tabular}

\subsection{Prefectural and cities resilience initiatives}

A key test of any such ostensibly collaborative initiative is how well it diffuses and how purposefully engaged the actors are. By May 1 of 2020, all of Japan's 47 prefectures had adopted their own regional versions of the NRP. Moreover, as a Table 7 shows, 1472 of Japan's 1741 cities, special wards, and towns had either adopted their own local versions of the NRP or were formulating plans. This number of local governments doing NRPs was more than seven times the 190 total from just over a year earlier, April 1 of 2019 [12,13]. That startling 775\% rate of increase in a little over a year is testament to the rapid spread of risk-awareness in Japan. Recent years of unprecedentedly destructive typhoons, floods and other disasters have led to a consensus on the need for comprehensive planning and integrated countermeasures. Japan's subnational governments now routinely request increased regular budget and special fiscal stimulus spending on NRP, SDGs, Society 5.0 projects and their integration. These fiscal and related requests are articulated collectively through such subnational representative organisations as the National Governors' Association, The National Mayors' Association and others.

An example of how the December 2019 fiscal stimulus was used at the subnational level is seen in Table 8 in Sapporo City. The table shows Sapporo's 2020 initial spend on economic stimulus, responding to the national government's December package, focused on close to JPY 19 billion for resilient and smart schools. Other spending included JPY 11.32 billion on bolstering the city's waterways, transport networks and other critical infrastructure. This emphasis on resilience is no surprise. Like many of Japan's subnational governments, Sapporo is aggressive in building on national policy to pursue integrated solutions to disaster, demographic, fiscal, and myriad other hazards. Sapporo was selected as one of the SDGs projects in June of 2018 and followed that up in December 2019 by revising the NRP it had adopted in January of 2016. Sapporo had already undertaken a Compact City Plan from March of 2016 and had also implemented a Smart City initiative from March of 2017. Sapporo is only one example of productive use of the fiscal stimulus within Japan's larger context of 2030-Agenda oriented platform institutions.

\section{Towards resilience building and long-term sustainability globally}

Having analysed Japan's financial stimulus in responding to COVID19 response from section 2 to 3, we turn to examine how integrated financial and economic stimulus can foster a rights-based, low carbon, resilient and sustainable recovery. The year 2020 was slated to be the "super year" of global action toward sustainability. The SDGs - also known as the Global Goals - were adopted by all United Nations Member States in 2015 as a universal call to action to end poverty, protect the

Table 7

Increase in Japan's local national resilience plans (NRPs) (Source: https://www. cas.go.jp/jp/seisaku/kokudo_kyoujinka/pdf/200401_keikakumap.pdf).

\begin{tabular}{lll}
\hline Administrative Level & April 1, 2019 & May 1, 2020 \\
\hline Local Government & 190 & 1472 \\
\hline
\end{tabular}

Table 8

Sapporo City's 2020 Economic Stimulus-Related Spending (unit: JPY billion) (Source: p 14 http://www.city.sapporo.jp/zaisei/kohyo/yosan-kessan/r2 /documents/r2gaiyouzentai.pdf).

\begin{tabular}{lll}
\hline Disaster-Recovery and Resilience: 20.9 & Resilient Schools & 9.36 \\
& Emergency Power & 0.24 \\
& Flood and Other & 11.32 \\
Future-Oriented Investment: 11.1 & ICT in Schools & 9.54 \\
\hline
\end{tabular}

planet, and ensure that all people enjoy peace and prosperity by 2030 . The 17 SDGs are integrated-that is, they recognize that action in one area will affect outcomes in others, and that development must balance social, economic and environmental sustainability. Through the pledge to Leave No One Behind, countries have committed to fast-track and prioritize progress for the most disadvantaged. That is why the SDGs are designed to achieve several 'zeros', including zero poverty, hunger, AIDS, and discrimination against women and girls. Broad stakeholder participation is needed to reach these ambitious targets. The creativity, knowhow, technology and financial resources from all elements of society are necessary to achieve the SDGs in every context. Moreover, through Nationally Determined Contribution (NDCs), countries show how they plan to meet the Paris Agreement on Climate Change [28]. In addition, the Sendai Framework for DRR calls for a comprehensive, multi-hazard and coherent approach (SFDRR, 2015).

Objectively speaking, integrating the 2030 Agenda is even more important in the midst of COVID-19. As IRENA (2020) puts it, "the goals set out in the United Nations 2030 Agenda and the Paris Agreement can serve as a compass to stay on course during this disorienting period. They can help to ensure that the short-term solutions adopted in the face of COVID-19 are in line with medium- and long-term development and climate objectives." The UN has also emphasized that the recovery from the COVID-19 crisis "must lead to a different economy" $[10,16]$. The International Resource Panel (IRP) has also pointed out that resource-efficient green stimulus packages can lead to cost savings, new industries, and equitable economic growth [29].

Evn so, public policy is clearly distracted by political polarization, geopolitical tensions, and other factors. In this section, we outline key implications if the fiscal response does not conform with the 2030 Agenda, both at the national level in Japan, and also globally.

\subsection{Increased inequality}

Emergency spending only to perpetuate the patently vulnerable status quo risks forfeiting opportunity to reduce a range of negative externalities that erode human health and welfare and have been implicated in the retreat of democracy (EIU, 2020). Concerning the US, Philip Alston, the UN Special Rapporteur on extreme poverty and human rights, pointed out that "[l] ow-income and poor people face far higher risks from the COVID-19 due to chronic neglect and discrimination, and a muddled, corporate-driven, federal response [that] has failed them" (OHCHR, 2020). The UN has also warned that coronavirus-driven debt crises threaten poor countries already at risk. It recommends accelerating investment in resilient infrastructure, strengthening social protections, enhancing regulatory frameworks, and strengthening the international financial safety net and framework for debt sustainability. And it strongly advises that this action be coordinated lest the larger opportunity be lost in the gaps among governance and other silos [30].

\subsection{Higher opportunity costs}

Opportunity costs are the pecuniary and other potential benefits forgone when one alternative is chosen over another. Specifically concerning fiscal countermeasures to COVID-19 and its economic fallout, failure to include climate action risks accelerated global warming. We have seen that the scale of COVID-19 counter-measures is already 
enormous, unprecedented in peacetime. Most countries lack the fiscal capacity and political will to continue such spending beyond one or two years, let alone for decades. Focused investment in public health systems - particularly in least developed countries - could reduce economic costs from future outbreaks as well as contribute to containing the present one [31]. For example, analyses suggest that in the US alone social distancing measures lead to net benefits of $\$ 5.2$ trillion [32]. These kinds of benefits could be multiplied by making the health investments climate-smart as well.

\subsection{Greater complexity and systemic risk}

Global connectedness has led to increased complexity. That complexity carries with it benefits for some but at the same time a hidden cost for all: fragility (Jensen, April 9, 2020). In finance, for example, interconnected institutions benefit from complex networks and reduced transaction costs, but have produced a fragile structure through which illiquidity and insolvency can become almost virulent during periods of financial distress (Billion et al., 2012). Similarly, COVID-19's unprecedented impact is rooted in complexity and fragility. Human ecosystem encroachment has led to a per-decade tripling of outbreaks since the 1980s, including ebola, HIV, swine flu, avian flu, and other viruses. Global interconnectedness has provided more human hosts, and inequality an abundance of compromised immune systems. This systemic reality risks accelerated evolution of mutations, and underscores the imperative of leaving no one behind. Emerging infectious diseases in humans are frequently caused by pathogens originating from animal hosts, and zoonotic disease outbreaks present a major challenge to global health [33].The overlap of human security and national security clearly transcends national borders.

Climate change and disaster risk offer additional examples of systemic risks that are embedded in the complex networks of an increasingly interconnected world. The Paris Agreement on Climate Change calls for limiting warming to $2^{\circ} \mathrm{C}$ and pursuing efforts for $1.5^{\circ}$ [34]. The IPCC [35] states that delaying actions for mitigating climate change leads to worsened climate risk and even greater efforts to cope with the impacts [36]. Indeed, the global community stands at the precipice of the soft and hard limits of adaptation increases, which may increase the loss and damages from climate change [37]. The interaction between natural and human-induced disasters is increasingly evident. Natural hazards can trigger technical and societal disasters, and hence natural and non-natural risks have multiplied (UNDRR, 2019). The systemic nature of disaster risk is exacerbated by the fact that that the events can be sudden and unexpected, the impacts are interlinked, and the dynamism may change over time. Disaster risk can also be compounded, such that one even triggers subsequent events. And multiple events - or cascading catastrophes - can unfold almost simultaneously. The global community must therefore increase its capacity to build resilience through risk-informed sustainable development (UNDRR, 2019). It is crucial that the SFDRR's lessons be used to strengthening the resilience of nations and communities for dealing with the health, disasters, and climate challenges [38].

\subsection{Increased risk of retreat from planetary thinking and globalism}

The ongoing fiscal stimulus packages have raised deep concerns among fiscal conservatives, market liberals and others concerning overreach of tax/debt states. The nearly inevitable increases in taxation and outrage over the contents of ongoing fiscal relief (eg, for airlines) could further weaken political coalitions supporting climate action and global engagement. In order to achieve a virtuous cycle of mitigation and adaptation, stakeholder inclusion and co-benefits must be maximized in least-cost solutions. Fiscal and other resources are not infinite, and 2030 Agenda solutions have to be robust against emergent political hazards.

In this regard, we have shown that Japan's National Resilience Program has built a strong foundation for equipping Japan to respond to large-scale crises from COVID-19. Its financial stimulus is characterized by long-term consideration for national and local resilience, along with a vision of Society 5.0. Japan has a powerful track record of managing large scale crises and complex recovery from natural and man-made disasters. It offers a pertinent example of how to do integrated planning, implementation, and revision through multi-stakeholder and increasingly all-hazard platforms. Japan integration of COVID-19 countermeasures and resilience merits closer study for lessons on least-cost and synergistic mitigation and adaptation. We would also urge that Japan use it stimulus packages even more productively, as a window of opportunity for implementing long-term sustainability and resilience.

In conclusion, it is a tall order to draft and implement a coherent strategy of COVID-19 countermeasures coupled with the 2030 Agenda. Global partnerships are critical to formulating and disseminating a global response. That is why goal 17 of the SDGs centres on strengthening global partnerships among national governments, the international community, civil society, the private sector and other stakeholders. The 2030 Agenda thus embodies the shared responsibility and global solidarity essential to making COVID-19 recovery a major step in the long journey back from planetary boundaries and towards sustainable and resilient communities.

\section{Declaration of competing interest}

The authors declare that they have no known competing financial interests or personal relationships that could have appeared to influence the work reported in this paper.

\section{References}

[1] WHO, WHO Director-General's Opening Remarks at the Media Briefing on COVID19 - 11 March 2020, 2020, 11 March.

[2] WHO, COVID-19 Situation Reports, 2020.

[3] IMF, World Economic Outlook, April 2020, The Great Lockdown, 2020.

[4] IMF, World Economic Outlook Update, June 2020: A Crisis like No Other, an Uncertain Recovery, 2020.

[5] ILO, ILO Monitor, COVID-19 and the World of Work, second ed., 2020 (COVID-19 and the world of work).

[6] ILO, ILO Monitor, COVID-19 and the World of Work, fifth ed., 2020 (COVID-19 and the world of work).

[7] UN HC, This Is, above All, a Human Crisis that Calls for Solidarity, 2020 (United Nations).

[8] UN Sol, Solidarity, Hope' and Coordinated Global Response Needed to Tackle COVID-19 Pandemic, Says UN Chief, 2020.

[9] G20, G20 Leaders' Statement, 2020.

[10] G.H.R.P. UN, Funding the Fight against COVID-19 in the World's Poorest Countries, 2020.

[11] EU, EU Solidarity Fund: Application Guidelines for Covid-19 Assistance, 2020.

[12] Japan Cabinet Secretariat, Economic and other countermeasures, in Japanese, 2020 (経済対策等 : 経済財政政策 - 内閣府).

[13] Japan Cabinet Secretariat, National resilience, in Japanese, 2020 (国土強勒化 |内 官房ホームページ).

[14] IMF, Policy Responses to COVID19, 2020.

[15] J. Lu, A Simple Way to Close the Multi-Trillion-Dollar Infrastructure Financing Gap, 15 April, the World Bank, 2020.

[16] UN, The Recovery from the COVID-19 Crisis Must Lead to a Different Economy, 31 March, 2020 (United Nations).

[17] UNEP/BNEF, Global Trends in Renewable Energy Investment 2019, Frankfurt School, 2019.

[18] IEA, The Impact of the Covid-19 Crisis on Clean Energy Progress, 2020.

[19] S. Evans, Carbon Brief, Analysis: coronavirus set to cause largest ever annual fall in CO2 emissions, 9 April, 2020.

[20] S. Hammer, S. Hallegate, World Bank, Planning for the Economic Recovery from COVID-19: A Sustainability Checklist for Policymakers, 14 April, 2020.

[21] Nobun Takemoto, Izumi Nakagawa, Focus: the COVID-19 Economic Countermeasures," Asahi Shimbun, March 23, in Japanese, 2020

[22] Japan Cabinet Secretariat, Comprehensive economic measures to create a future with security and growth, in: December 5, 2019.

[23] Johns Hopkins University, COVID-19 Dashboard, 2020. https://www.arcgis.com/a pps/opsdashboard/index.html\#/bda7594740fd40299423467b48e9ecf6.

[24] Aleksandrina Mavrodieva, Rajib Shaw, Disaster and climate change issues in Japan's society 5.0 - a discussion, Sustainability 12 (5) (2020).

[25] CAO, Cabinet Office of Japan, Society 5.0 (2020).

[26] Sachiko Seki, Concerning the Promotion of Japanese-Style SDGs," Governance, October, 2019, in Japanese, 2019. 
[27] Andrew DeWit, Riyanti Djalante, Rajib Shaw, "Building holistic resilience: Tokyo's 2050 strategy, Asia-Pacific J. 18 (7) (2020).

[28] UNFCCC, Nationally determined contributions (NDCs), 2020.

[29] IRP, Building Resilient Societies after the Covid-19 Pandemic, 2020.

[30] UNDP, The Social and Economic Impact of Covid-19 in the Asia-Pacific Region, 2020.

[31] Warwick J. McKibbin, Roshen Fernando, The Global Macroeconomic Impacts of COVID-19: Seven Scenarios, 2020.

[32] Linda Thunstrom, Newbold Stephen, David Finnoff, Madison Ashworth, Jason F. Shogren, The benefits and costs of flattening the curve for COVID-19, 2020. Available at: SSRN 3561934.

[33] C.K. Johnson, P.L. Hitchens, P.S. Pandit, J. Rushmore, T.S. Evans, C.C. Young, M. M. Doyle, Global shifts in mammalian population trends reveal key predictors of virus spillover risk, Proceed. Roy. Soc. B 287 (1924) (2020) 20192736.

[34] Joeri Rogelj, Michel Den Elzen, Niklas Höhne, Taryn Fransen, Fekete Hanna, Harald Winkler, Roberto Schaeffer, Sha Fu, Keywan Riahi, Malte Meinshausen, Paris Agreement climate proposals need a boost to keep warming well below 2 C, Nature 534 (7609) (2016) 631-639.
[35] IPCC, Summary for policymakers, in: V. Masson-Delmotte, P. Zhai, H.O. Pörtner, D. Roberts, J. Skea, P.R. Shukla, A. Pirani, W. Moufouma-Okia, C. Péan, R. Pidcock, S. Connors, J.B.R. Matthews, Y. Chen, X. Zhou, M.I. Gomis, E. Lonnoy, T. Maycock, M. Tignor, T. Waterfield (Eds.), Global Warming of $1.5^{\circ} \mathrm{C}$. An IPCC Special Report on the Impacts of Global Warming of $1.5^{\circ} \mathrm{C}$ above Pre-industrial Levels and Related Global Greenhouse Gas Emission Pathways, in the Context of Strengthening the Global Response to the Threat of Climate Change, Sustainable Development, and Efforts to Eradicate Poverty, 2018.

[36] O. Hoegh-Guldberg, D. Jacob, M. Bindi, S. Brown, I. Camilloni, A. Diedhiou, R. Djalante, K. Ebi, F. Engelbrecht, J. Guiot, Y. Hijioka, Impacts of 1.5 C global warming on natural and human systems, in: Global Warming of $1.5^{\circ} \mathrm{C}$. An IPCC Special Report, 2018.

[37] R. Mechler, C. Singh, K. Ebi, R. Djalante, A. Thomas, R. James, P. Tschakert, et al., Loss and Damage and limits to adaptation: recent IPCC insights and implications for climate science and policy, Sustain. Sci. (2020). https://link.springer.com/con tent/pdf/10.1007/s11625-020-00807-9.pdf.

[38] R. Djalante, R. Shaw, A. DeWit, Building resilience against biological hazards and pandemics: COVID-19 and its implications for the Sendai Framework, Progress Disaster Sci. (2020) 100080. 